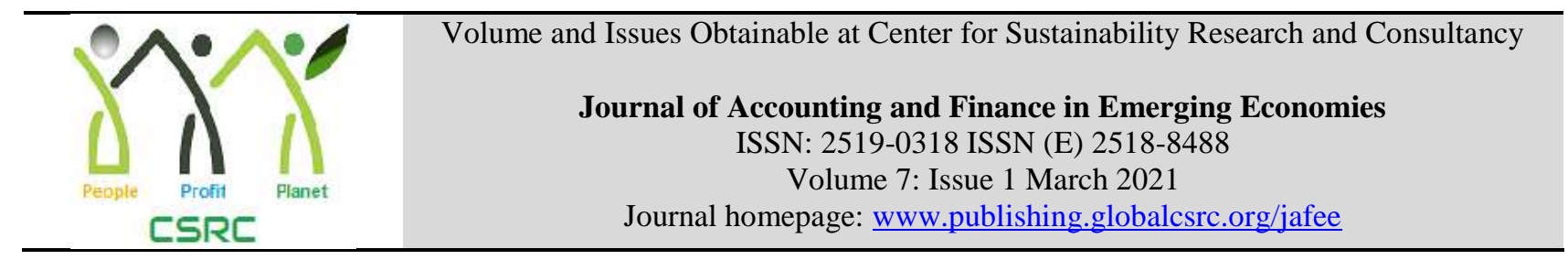

\title{
The Risk and Return Relations: New Evidence from Pakistani Stock Market
}

\author{
${ }^{1}$ Syed Hamid Ali Shah, ${ }^{2}$ Attaullah Shah, ${ }^{3}$ Muhammad Kamran Khan, ${ }^{4}$ Hamid Ullah, \\ ${ }^{1}$ Quaid-e-Azam College of Commerce, University of Peshawar, Pakistan, hamidqcc@upesh.edu.pk \\ ${ }^{2}$ Institute of Management Sciences, Peshawar, Pakistan, attaullah.shah@imsciences.edu.pk \\ ${ }^{3}$ Bacha Khan University, Charsadda, Pakistan, drkamrankhan@bkuc.edu.pk \\ ${ }^{4}$ Islamia College University, Peshawar, Pakistan, hamidullah@icp.edu.pk

\begin{tabular}{|c|c|}
\hline ARTICLE DETAILS & ABSTRACT \\
\hline History & In this study, we try to answer several empirical questions related to \\
\hline Revised format: February & testing of asset pricing models in Pakistan. First, we test the \\
\hline 2021 & assumptions of capital asset pricing model (CAPM) using cross- \\
\hline Available Online: March & sectional regression methodology of Fama and MacBeth (FMB) \\
\hline 2021 & (1973). Second, we test the conditional relationship between beta \\
\hline Keywords & and expected returns using FMB cross-sectional regressions. Third, \\
\hline CAPM, Risk and retu & we test and compare the explanatory power of CAPM and Fama and \\
\hline series regression, Fam & French (1993) three factor models using time-series regressions. For \\
\hline French (1993) three factor & all of the above empirical tests, we use sufficiently large data set of \\
\hline $\begin{array}{l}\text { model, Pakistan Stock } \\
\text { Exchange }\end{array}$ & $\begin{array}{l}\text { weekly data from January } 2006 \text { to December } 2018 \text { of non-financial } \\
\text { firms listed at the Pakistan Stock Exchange. Results of the cross- }\end{array}$ \\
\hline JEL Classification: & sectional regressions suggest that beta cannot explain expected \\
\hline$M 40, M 41$ & returns. However, there is weak evidence that a conditional relation \\
\hline & exits between beta and expected returns. Results of the time-series \\
\hline & regression suggest that both CAPM and three factor model do well \\
\hline & $\begin{array}{l}\text { in explaining expected returns. However, GRS-based test of } \\
\text { regression intercepts and regressions } R^{2} \text { indicate that Fama and }\end{array}$ \\
\hline & $\begin{array}{l}\text { French model better captures variations in observed stock returns } \\
\text { than the CAPM. }\end{array}$ \\
\hline
\end{tabular}

\section{OPEN ACCESS}

(C) 2021 The authors, under a Creative Commons Attribution-

NonCommercial 4.0

Corresponding author's email address: hamidqcc@upesh.edu.pk

Recommended citation: Shah, S. H. A., Shah, A., Khan, M. K. \& Hamidullah. (2021). The Risk and Return Relations: New Evidence from Pakistani Stock Market. Journal of Accounting and Finance in Emerging Economies, 7(1), 195-204

\section{Introduction}

Corporate risk management is important due to its potential implications on stock prices and investors' returns. The prime objective of any business firm is the share value maximization (Damodaran, 2016). In the long run this is line with the interests of almost all the stakeholders of the firm. In the simplest and perfect environment discounted value of future cash flows can be considered the appropriate value of a firm. Increasing cash flows through exploiting growth opportunities in order to increase returns and value also demand to accept more risk (Shimko \& Humphreys, 1998). However, rationale investors maximize their returns for certain level of risk or reduce their risks given certain level of returns (Markovitz, 1952). Due to the risk-return link with asset pricing in financial capital markets, the risk 
dimension in investment decision is so important that there is no need to convince people to include it in their analysis. Expected rate of return can be maximized through diversification for given level of risk by pooling different assets with lesser covariance (Markovitz, 1952). However, variations in marketwide conditions cannot be completely diversified and cause fluctuations in the prices of financial assets (Lettau \& Ludvigson, 2010). Moreover, investment markets do not compensate for diversifiable risk and only reward the non-diversifiable risk (Sharpe, 1965). Therefore, the most plausible addition to a portfolio is an asset that shows the minimum covariance with the market but if otherwise desired by an investor; say for example opting for a security that varies exactly with the market.

It is generally argued that risk and stocks return relationship in emerging markets is different from that observed in developed stocks markets. In the case of emerging markets, the presence of stock prices volatility, unexpected high returns and serial autocorrelation in returns are reported and presence of leptokurtosis, skewness and volatility clustering in these markets are observed (Fayyad \& Daly, 2010). The later characteristics were reported in Karachi Stock Exchange (KSE) also (see e.g., Hussain \& Uppal, 1998). In Pakistan, investors are not well-diversified for several reasons such as family ownership, group ownership, shallow market, and thin trading volume etc. This gives us fair justification to believe that both systematic and unsystematic risks are relevant, and hence beta under-estimates the risk premium. The results of this study shall determine the degree of receptiveness of stocks' returns of Pakistani listed companies to market-wide factors and to factors unique to a firm or industry. Indeed, variety of stakeholders for example, financial analysts, investors and business managers etc. might have interest in such analysis for variety of reasons. More specifically, this study investigates if systematic risk factor alone is relevant or some other aspects of risk are also of matter of concern for investors in Pakistani stock market. In this study we investigate risk and stock returns relationship while employing capital asset pricing model of Sharpe (1965) and Lintner (1966) and three factor model of Fama \& French (1993) [FFM] to determine which of the two models can better explain stock returns in the market. We test CAPM model using both cross-sectional and time series approaches. In addition, we explore the explanatory power of CAPM in up and down market condition as proposed by Pettengill, Sundaram, \& Mathur (1995). Our paper contributes to the extant literature about risk and return in following ways. First, this study uses two different models and estimation approaches to compare the explanatory power of the models by conducting Gibbons, Ross \& Shanken (1989) [GRS] statistics. Second, the results of the study are based on rich data set of up to 720 firms for the period from January 1, 2006 to December 31, 2018. The results are easy to interpret and suggest that in cross-sectional estimation procedure CAPM fails to explain risk and return relationship as beta turns insignificant; where the beta is significant at $10 \%$ and $5 \%$ in up and down market conditions, respectively . However, in time series estimation approach both CAPM and FFM produce significant results on betas. However, the GRS statistics indicate that FFM has more explanatory power than CAPM as the former has intercept value of zero and higher adjusted $\mathrm{R}^{2}$ value. However, the $\mathrm{R}^{2}$ values of FFM also suggest that in Pakistan's stock market other common risk factors also has role in explaining risk and returns relationship.

Section 1 introduces the study. Section 2 describes the relevant and brief literature review of the topic. Section 3 introduces the methodology and Section 4 discusses the results and concludes.

\section{Literature Review}

Past, present and future discounted events are related to financial assets' prices but do not explain changes in prices of these assets (Brockwell \& Davis, 2016). Later, it is explained that for a given expected rate of return, assets' risk can be minimized through diversification (Markovitz, 1952). He explained that investors who care about the trade-off between risk and return can identify most economical set of portfolios on efficient frontier, for a given level of risk with the highest expected returns. Empirical studies show that by adding as few as ten or more securities the effect of diversification could be achieved implying that diversification process takes place quickly (Maillard, Roncalli \& Teïletche, 2010). Due to their different level of risk propensity, investors allocate funds to 
cash or risk-free assets differently, however, the single optimal risky portfolio is the market portfolio with maximum expected returns and minimum associated risk in all set of portfolios on the efficient frontier (Tobin, 1958). Though it made the process of portfolio selection simple but the Morkovitz model was effusively utilized with the emergence of the CAPM (Sharpe, 1964; Mossin, 1966; and Litner, 1965).

As per CAPM, security required rate of return is independent of specific risk for it can be eliminated trough efficient portfolio formation. Under the CAPM, systematic or market risk is the relevant risk that relates return of individual and/or portfolio of risky securities to that of market portfolio in linear fashion. The CAPM model assumes that (i) investors are risk averse, (ii) have homogeneous expectations of maximizing expected utility, (iii) they may borrow or lend unlimited amounts of risk free asset at a constant rate, (iv) all assets are divisible and priced efficiently, and (v) markets are perfect and frictionless for all investors. An analysis of returns of 63 shares from about six different industries for the period 1927-1960 revealed that share prices co-varied with the overall market return (King, 1966). Traditional CAPM is empirically supported in few studies (see for example Fama \& MacBeth, 1973).

Other financial management scientists tried to relax these assumptions and thus resulted in producing modified versions of CAPM. One author showed in the presence of taxes that the original CAPM is valid (Brennan, 1970). The most cited zero-beta CAPM addresses the assumption of riskless borrowing availability (Black, 1972). Allowing for international investments it is concluded that CAPM is reliable (Solnik, 1974). The model is reported to be robust even if the assumption pertaining to investors' homogenous return expectations are relaxed (Williams, 1977). The practical outcome of these studies now is that people hold pool of versions of risk free, risky assets and assets that move with the market to insure their expected returns. Many other studies however examined the stock returns co-movement with one another with the view of their sensitivity to the overall market and introduced multi factors models rather than using single factor model (Chen, Roll \& Ross, 1986). Similarly, traditional CAPM is found to be unable to explain expected return and risk relationship in a dynamic setting therefore to account for the required more betas an intertemporal CAPM is introduced (Merton, 1973). This intertemporal CAPM elaborates that an investor who is currently exposed to one interest rate and in future he/ she expects some other interest rate will have different portfolios demands and cannot rely upon a single horizon expectation.

In line with the CAPM, In the Brussels stock market it is reported that investors' returns are explained by systematic risk (Hawawini \& Michel, 1982) however in another study in French stock market it is found that though average returns are related to systematic risk of beta and stock returns are negatively related due to the poor performance of the stock market (Hawawini, Michel, \& Viallet, 1983). In the case of US stock market data from 1935 to 1968 positive tradeoff between risk and return, influenced by beta, is reported and it is contended that these results support CAPM (Fama \& MacBeth, 1973). However, as the risk and return were not significant across sub-periods so it is argued that this was the case of weak support (Schwert, 1983). Other authors argued that in up market condition (down market condition) beta is positively (negatively) related to the realized returns. Consistent with this conditional framework in US stock market, strong support for beta is documented (Pettengill, Sundaram, \& Mathur, 1995). Positive (negative) relation between beta and realized returns is reported when market excess returns were positive (negative) in Singapore stock market from April 1986 to December 1998 using the conditional framework (up and down markets) (Tang \& Shum, 2004). In addition, they also reported that unsystematic risk has an impact in pricing risky assets and concluded that in pricing risk, along with beta of the assets other stock characteristics shall also be considered as investors do not necessarily hold diversified portfolios. In Swiss stock market, using conditional framework procedure it is reported that beta is statistically significant and carried the expected sign and therefore concluded that beta is still reliable (Isakov, 1999). In Pakistan, on the basis of unconditional and conditional higher-moment capital asset pricing model (CAPM), it is reported that three-moment CAPM could explain the risk-return 
relation relatively better; however, both the systematic covariance and cokurtosis contribution to explain asset prices in KSE was marginal (Javid, 2009). Against the efficacy of CAPM it is reported that the cross-sectional differences in estimated portfolio betas based on common market indices and the differences in returns of these portfolios are not reliably related, more specifically, it is reported that the returns are not significantly higher for high-beta portfolios relative to low-beta portfolios (Reinganum, 1981). Similarly, in the case of the largest 1000 US stocks for the period of $1972-1989$ it is reported that low-risk stocks have abnormally high returns (Haugen \& Baker, 1991). Other studies report different anomalies and factors that influence risk and returns relationship. Some studies showed that in a particular month/ day (e.g. January) risk premium is higher and when data of that particular period is excluded it is found that risk premiums become statistically insignificant (Tinic \& West, 1984). Similarly, some studies have also shown that beta is not the only relevant factors and other factors such as size, earnings/price ratio, cash-flow/price ratio, book-to-market equity ratio, and past sales growth significantly explain variation in average stock returns (see for example, Banz, 1981; Basu, 1977; Chan, Hamao \& Lakonishok, 1991; Chui \& Wei, 1998; Fama \& French, 1992; and Lakonishok \& Shapiro, 1986).

Fama \& French (1993) proposed a model that is an extended form of CAPM. FF added size and value factors in the CAPM equation. According to FFM, small cap and value stocks outperform the stock market in persistent manner. Therefore, both size and value can serve as common risk factors. Fama \& French (1993) provide strong evidence that in the presence of excess market return [EMR], both returns for size and book-to-market ratio [BMR] appear to be robust common risk factors to explain crosssectional returns. In explaining the theoretical justification of using the two factors, they argue that BMR persistently relate to firms' return on assets (ROA) such that low (high) BMR firms are expected to have high (low) ROA. Likewise, size is related to ROA of firms such that big (small) firms have higher (lower) ROA. They find that small (big) firms experience longer (shorter) earning depression in recessions and relative to big firms, small firms cannot take advantage of an economic boom.

The discussion though very briefly, however, describes that there are empirical deficiencies in CAPM to correctly capture the relationship between expected returns and the market risk factor. In this study we investigate if risks factors other than EMR are involved in pricing securities in the Pakistani stock market? Also, we investigate whether cross-sectional and time series methods of testing models matters? The following methodology is adopted to meet the purpose of the study.

\section{Methodology}

\subsection{Sample and Data Sources}

Weekly data of closing stock prices for up to 431 non-financial firms ${ }^{1}$ listed on the KSE (now PSX) for 678 weeks, starting from January, 1, 2006 to December 31, 2018 is downloaded from the website of Pakistan Stock Exchange (PSX). We also downloaded closing weekly data on the 100 Index for the same period. We calculated log stock returns and log index returns through stock prices data and market index data. Weekly t-bills rates were used a proxy for risk-free asset. The data was downloaded from the official website of the State Bank of Pakistan (SBP). Financial data on total number of outstanding shares and book equity of firms are collected from the SBP website and annual reports of the firms for the period. This data is used to calculate the two risk factors i.e., size and book to market ratio (BMR). Firms with equity less than zero and/ or stock market price less than Rs.1 are excluded from the sample.

1

\begin{tabular}{|c|c|c|c|c|c|c|c|c|c|c|c|c|c|}
\hline Year & 2006 & 2007 & 2008 & 2009 & 2010 & 2011 & 2012 & 2013 & 2014 & 2015 & 2016 & 2017 & 2018 \\
\hline Freq. & 418 & 431 & 375 & 373 & 376 & 391 & 391 & 369 & 373 & 360 & 366 & 352 & 336 \\
\hline Percent & 8.51 & 8.78 & 7.64 & 7.6 & 7.66 & 7.96 & 7.96 & 7.51 & 7.6 & 7.33 & 7.45 & 7.17 & 6.84 \\
\hline Cum. & 8.51 & 17.29 & 24.92 & 32.52 & 40.18 & 48.14 & 56.1 & 63.61 & 71.21 & 78.54 & 85.99 & 93.16 & 100 \\
\hline
\end{tabular}




\subsection{The Models}

This study uses multiple methods to investigate risk and return (R-R) relation. The first method uses cross-sectional regression technique of Fama \& MacBeth (1973) to test validity of the CAPM model. In the second set of regression models, we use time series regressions technique to test validity of CAPM and Fama and French models. These methods are explained in the following text.

\subsubsection{Cross-sectional Regression}

First, the entire length of sample (678 weeks) is divided into three sub-periods and as such data of first 226 week is used to estimate betas $\left(\beta_{\mathrm{i}}\right)$ for each security through Eq -1 . Firms are then ranked and classified into forty portfolios on the basis of their $\beta_{\mathrm{i}}$ such that firms in first (last i.e., $40^{\text {th }}$ ) portfolio has the lowest (highest) $\beta_{\mathrm{i}}$. Portfolios formation under this procedure is required to cater for the diversifiable risk and then to use portfolios betas instead of individual stocks betas in the last step. It is generally argued that when testing reliability of beta on the CAPM, portfolios returns are preferred due to its lower estimation errors and contained specific risks.

$$
\left.\left(R_{i}-R_{f}\right)=\alpha+\beta_{i}\left(R_{m}-R_{f}\right)+\varepsilon_{i} \ldots \ldots \ldots \ldots \ldots \ldots \ldots \ldots . . \ldots \ldots \ldots+1\right]
$$

In the second step, data from week $227^{\text {th }}$ through week $452^{\text {nd }}$ is used to estimate $\beta_{\text {i }}$ of the firms and forty $\beta_{\mathrm{p}}$ are computed by averaging $\beta_{\mathrm{i}}$ across securities within portfolios. The data in the last sub-period is used to calculate week by week equal weighted average portfolio returns $\left(R_{P i}\right)$.

CAPM suggests that portfolios' betas $\left(\beta_{P i}\right)$ shall explain portfolios' returns $\left(R_{P i}\right)$ in linear fashion and hence we estimate [Eq-2]. In this model, $R_{P i}$ is the rate of return of ith portfolio, $\gamma_{i}$ is the rate of responsiveness of portfolio returns per unit of portfolio systematic risk and $\varepsilon_{\mathrm{i}}$ is the usual error term of the regression.

$$
R_{P i}=\alpha+\gamma_{i}\left(\beta_{P i}\right)+\varepsilon_{i} \ldots \ldots \ldots \ldots \ldots . . .[\mathrm{Eq}-2]
$$

Initially [Eq-2] is estimated for the entire set of values of $R_{P i}$ and $\beta_{\mathrm{pi}}$ and then for up $\left(R_{m}>0\right)$ and down $\left(R_{m}<0\right)$ market conditions to test whether conditional relation between expected returns and betas exists?

\subsubsection{Time Series Regression}

We use this technique and estimate FFM and CAPM and compare results of the two through GRS statistics. The procedure(s) adopted is explained below.

\subsubsection{FFM}

Mathematical form of the model is shown in Eq-3. Here, the term $\left(R_{p i, t}-R_{f, t}\right)$ symbolizes weekly excess portfolio returns. $R_{f, t}$ is the weekly rate of nine month t-bills. $\left(R_{m, t}-R_{f, t}\right)$ is weekly excess market portfolio returns. $S M B_{i, t}$, refers to size and is the difference of returns of portfolios of small cap and low cap stocks. $H M L_{i, t}$ is the value factor and is the difference of returns of portfolios of high BMR and low BMR. $\beta_{i, t}, s_{i, t}, h_{i, t}$, are the coefficients of the three explanatory variables and $\alpha_{i, t}$ and $\varepsilon_{i, t}$ are the intercepts and error terms of the regression.

$$
\left.\left(R_{p i, t}-R_{f, t}\right)=\alpha_{i, t}+\beta_{i, t}\left(R_{m, t}-R_{f, t}\right)+s_{i, t}\left(S M B_{i, t}\right)+h_{i, t}\left(H M L_{i, t}\right)+\varepsilon_{i, t} \ldots \ldots \ldots \ldots \ldots . . .6 \mathrm{Eq}-3\right]
$$

Stocks are independently allocated to either small or big groups if market equity of the stock is below or above the median market equity of stocks. Similarly, stocks are also sorted into three groups on the basis of low, medium and high BMR where bottom 30\% stocks are placed in low group, middle $40 \%$ are placed in medium and remaining 30\% are placed in the high BMR groups respectively. Finally, six portfolios are formed from the intersection of the two size and three value groups. Weekly excess portfolios return of the portfolios are calculated by averaging excess individual stock returns in these portfolios. Where weekly individual excess stock return is calculated through Eq-4, where $R_{i, t}$ is the excess return of individual stock, $\mathrm{P}_{\mathrm{t}+1}$ and $\mathrm{P}_{\mathrm{t}}$ are closing stock prices at the end and beginning of period $\mathrm{t}$ and $R_{f, t}$ is weekly annualized risk free rate.

$$
\left.\mathrm{R}_{\mathrm{i}, \mathrm{t}}=\ln \left(\mathrm{P}_{\mathrm{t}}+1 / \mathrm{P}_{\mathrm{t}}\right)-R_{f, t} \ldots \ldots \ldots \ldots \ldots \ldots \ldots \ldots \ldots \ldots \ldots \ldots+4\right]
$$

For each week average returns of the three big stock (the two low BMR) portfolios is subtracted from average returns of the three-small stock (the two high BMR) portfolios to calculate SMB (HML). Then twenty-five portfolios are constructed and weekly excess returns for these portfolios are calculated. On 
the basis of size sort, all stocks in the sample are distributed into five groups $\left(\mathrm{S}_{1}\right.$ to $\left.\mathrm{S}_{5}\right)$. Likewise, on the basis of value sort, stocks are independently allocated to another five groups $\left(\mathrm{H}_{1}\right.$ to $\left.\mathrm{H}_{5}\right)$. From the intersection of the five size and value sort groups, twenty-five portfolios are constructed. For example, $\mathrm{S}_{1} \mathrm{H}_{1}$ portfolio is the combination of the smallest capital and the highest BMR stocks and $\mathrm{S}_{5} \mathrm{H}_{5}$ is the combination of the biggest capital and the lowest BMR stocks.

\subsubsection{CAPM}

Mathematical form of the model is shown in Eq-5. All components of the model are already explained in Section 3.2.2.1 above.

$$
\left(R_{p i, t}-R_{f, t}\right)=\alpha_{i, t}+\beta_{i, t}\left(R_{m, t}-R_{f, t}\right)+\varepsilon_{\mathrm{i}, \mathrm{t}} \ldots \ldots \ldots \ldots \ldots \ldots[\mathrm{Eq}-5]
$$

Model $3 \& 5$ are compared to determine which one can better predict risk and returns relationship in stock market of Pakistan. To meet the purpose GRS - statics is computed which tests if estimated intercepts of multiple regressions are statistically insignificant.

\section{Results and Discussion}

This section contains the results obtained from the two different methods and models. Descriptive statistics and results of the cross-sectional regressions are reported in Table $1 \& 2$, respectively. Descriptive statistics and regression results of the FFM are reported in Table $3 \&$ and Panel A of Table 4 , respectively. Where, regression results of the time series CAPM are reported in Panel B of Table 4 and panel $\mathrm{C}$ of the table shows results of the GRS test.

Table 1: Summary Statistics of the Forty Portfolios Returns with $\mathbf{t}$ - test

\begin{tabular}{|c|c|c|c|c|c|c|c|c|c|c|c|c|c|}
\hline P.folios & Mean & Median & Min & Max & Std. D. & t-Stat. & P.folios & Mean & Median & Min & Max & Std. D. & t-Stat. \\
\hline 1 & 0.004 & -0.002 & -0.131 & 0.163 & 0.046 & 1.281 & 21 & 0.004 & 0.001 & -0.101 & 0.180 & 0.037 & 1.454 \\
\hline 2 & 0.001 & 0.000 & -0.202 & 0.272 & 0.050 & 0.356 & 22 & 0.005 & 0.005 & -0.119 & 0.153 & 0.038 & 1.561 \\
\hline 3 & 0.003 & -0.003 & -0.168 & 0.250 & 0.049 & 0.792 & 23 & 0.005 & -0.001 & -0.143 & 0.201 & 0.059 & 1.207 \\
\hline 4 & 0.001 & -0.001 & -0.147 & 0.197 & 0.043 & 0.379 & 24 & 0.003 & 0.003 & -0.113 & 0.126 & 0.039 & 0.982 \\
\hline 5 & 0.005 & 0.002 & -0.189 & 0.252 & 0.048 & 1.294 & 25 & 0.003 & 0.003 & -0.142 & 0.176 & 0.045 & 0.895 \\
\hline 6 & 0.003 & 0.003 & -0.241 & 0.169 & 0.050 & 0.731 & 26 & 0.001 & -0.001 & -0.112 & 0.148 & 0.037 & 0.429 \\
\hline 7 & 0.000 & -0.003 & -0.191 & 0.217 & 0.054 & 0.078 & 27 & 0.006 & 0.003 & -0.093 & 0.151 & 0.034 & 2.339 \\
\hline 8 & 0.004 & 0.000 & -0.079 & 0.146 & 0.038 & 1.281 & 28 & 0.006 & 0.001 & -0.562 & 0.531 & 0.077 & 0.966 \\
\hline 9 & 0.002 & 0.002 & -0.109 & 0.098 & 0.034 & 0.730 & 29 & 0.006 & 0.002 & -0.298 & 0.399 & 0.066 & 1.198 \\
\hline 10 & -0.000 & 0.000 & -0.119 & 0.123 & 0.037 & -0.071 & 30 & 0.003 & -0.001 & -0.289 & 0.220 & 0.056 & 0.800 \\
\hline 11 & 0.004 & 0.003 & -0.217 & 0.173 & 0.051 & 1.001 & 31 & 0.006 & 0.008 & -0.143 & 0.133 & 0.044 & 1.797 \\
\hline 12 & 0.005 & 0.005 & -0.118 & 0.180 & 0.037 & 1.875 & 32 & 0.005 & 0.003 & -0.177 & 0.222 & 0.054 & 1.307 \\
\hline 13 & 0.003 & -0.000 & -0.111 & 0.152 & 0.037 & 1.159 & 33 & 0.005 & -0.003 & -0.274 & 0.339 & 0.073 & 0.908 \\
\hline 14 & 0.002 & 0.001 & -0.109 & 0.087 & 0.031 & 0.954 & 34 & 0.003 & -0.000 & -0.123 & 0.197 & 0.045 & 0.942 \\
\hline 15 & 0.004 & 0.001 & -0.107 & 0.129 & 0.035 & 1.451 & 35 & 0.003 & 0.001 & -0.130 & 0.233 & 0.046 & 0.765 \\
\hline 16 & 0.003 & -0.000 & -0.096 & 0.081 & 0.034 & 1.051 & 36 & 0.004 & 0.001 & -0.116 & 0.211 & 0.048 & 1.068 \\
\hline 17 & 0.004 & -0.001 & -0.130 & 0.223 & 0.051 & 1.033 & 37 & 0.001 & -0.005 & -0.152 & 0.215 & 0.058 & 0.161 \\
\hline 18 & 0.002 & -0.004 & -0.180 & 0.195 & 0.053 & 0.574 & 38 & 0.004 & 0.004 & -0.153 & 0.106 & 0.042 & 1.165 \\
\hline 19 & 0.003 & 0.000 & -0.205 & 0.233 & 0.049 & 0.876 & 39 & 0.004 & 0.004 & -0.313 & 0.130 & 0.048 & 1.017 \\
\hline 20 & 0.004 & 0.001 & -0.127 & 0.124 & 0.047 & 1.006 & 40 & -0.000 & 0.000 & -0.187 & 0.206 & 0.050 & -0.120 \\
\hline
\end{tabular}

In Table 1 above portfolios' mean (median) returns, in general, hardly show any significant variation. $1^{\text {st }}$ portfolio has weekly mean returns of 0.004 where $40^{\text {th }}$ portfolio's mean return is 0.000 . Moreover, $\mathrm{t}-$ statistics suggests that except for $27^{\text {th }}$ portfolio mean returns of all the portfolios are not different than zero.

Table 2: Fama-MacBeth (1973) Two-Step Regressions of Forty Portfolios

\begin{tabular}{cccc}
\hline 1 & $\mathbf{2}$ & $\mathbf{3}$ & $\mathbf{4}$ \\
\hline & FMB Full & FMB Up Market & FMB Down Market \\
\hline Bpi & 0.000 & $0.009 * * *$ & $-0.014 * * *$ \\
& $(0.170)$ & $(3.002)$ & $(-4.465)$ \\
Constant & 0.003 & $0.009 * * *$ & $-0.007 * *$ \\
& $(1.528)$ & $(3.432)$ & $(-2.477)$ \\
$\mathbf{R}^{2}$ & 0.064 & 0.063 & 0.066 \\
Observations & 6960 & 4480 & 2480 \\
\hline Note: $\beta$ pi is the portfolios beta; t-statics are in parentheses; and $* * * \mathrm{p}<0.01, * * \mathrm{p}<0.05, * \mathrm{p}<0.1$
\end{tabular}

Table 2 reports results of cross-sectional regression of CAPM. Results of regressions on all stocks in Column 2 show insignificant beta. These findings are not in line with the theoretical claim of CAPM. However, the findings are not unique particularly in the case of a negative and insignificant beta. For 
example, Hawawini et al., (1983) reported negative beta for poor performing French stock market. Numbers of different studies reported such instances. These results are similar to those of Fama \& MacBeth (1973) who reported positive and significant beta for the whole period but the beta was insignificant in the sub-period regressions. There are studies those rejected the practicality of beta and suggested that other measures can explain returns more efficiently (see e.g. Chan, Hamao \& Lakonishok, 1991; Fama \& French, 1992). However alternative reason for the evidence of insignificant and/or negative beta in so called unconditional regression estimation is given by Pettengill et al., (1995). However, even their explanation falls short to sufficiently explain variation in portfolios returns through beta. As reported in Column $3 \& 4$ of Table 2, under up market condition i.e., $\mathrm{R}_{\mathrm{m}}>0$ portfolios' beta is statistically significant at $1 \%$ and it is significant and negative at $1 \%$ in down market condition i.e., $R_{m}<$ 0 . The $\mathrm{R}^{2}$ values are below $10 \%$, and all three cases indicative of the fact that only small part of variation in portfolio returns is explained by common market risk factor and suggest that probably there are some other common factors which are valued by investors in the stock markets of Pakistan.

Mean annualized returns and standard deviations, minimum and maximum values of market (index) portfolio $\left(\mathrm{R}_{\mathrm{m}}-\mathrm{R}_{\mathrm{f}}\right.$ ), small minus big stocks (SMB), high minus low BMR stocks (HML) and of the twenty-five portfolios (S1H1 through S5H5) constructed from the intersection of five size and five value groups are reported in Table 3. The table also shows the corresponding numbers of observations. Mean annualized returns of market portfolio, SMB, and HML are 0.136, 0.131, and -1.055 respectively. Portfolio constructed from stocks in the smallest size group and the highest BMR group has greater annualized average returns than portfolio constructed from stocks in the biggest size group and the lowest BMR group (0.688 \& -1.673). In terms of effective annual rate this difference is more than $50.0 \%$.

Table 3: Descriptive Statistics of Variables of Fama \& French Model

\begin{tabular}{|c|c|c|c|c|c|c|c|c|c|c|c|}
\hline Var. & Obs & Mean & Std.Dev. & Min & Max & Var. & Obs & Mean & Std.Dev. & Min & Max \\
\hline SMB & 668 & 0.131 & 2.252 & -12.072 & 16.715 & S3H2 & 672 & 0.516 & 3.390 & -16.980 & 27.416 \\
\hline HML & 668 & -1.055 & 2.683 & -25.683 & 14.195 & S3H3 & 673 & 0.163 & 3.167 & -12.943 & 10.718 \\
\hline Rm_Rf & 622 & 0.136 & 3.224 & -21.024 & 11.765 & S3H4 & 674 & -0.062 & 3.617 & -28.647 & 15.735 \\
\hline S1H1 & 628 & 0.688 & 11.177 & -118.562 & 48.124 & S3H5 & 671 & -0.357 & 4.960 & -34.068 & 18.515 \\
\hline S1H2 & 655 & 0.912 & 9.386 & -74.999 & 54.784 & S4H1 & 667 & 0.679 & 3.427 & -20.494 & 26.309 \\
\hline S1H3 & 658 & 0.418 & 6.941 & -31.292 & 32.788 & S4H2 & 672 & 0.218 & 3.190 & -18.941 & 11.278 \\
\hline S1H4 & 671 & 0.161 & 5.668 & -36.542 & 38.146 & S4H3 & 674 & 0.054 & 3.214 & -15.538 & 11.663 \\
\hline S1H5 & 674 & -1.080 & 5.744 & -53.508 & 27.864 & S4H4 & 670 & -0.016 & 3.651 & -16.794 & 18.091 \\
\hline S2H1 & 625 & 1.108 & 7.429 & -39.262 & 51.992 & S4H5 & 513 & -0.557 & 6.464 & -44.645 & 29.979 \\
\hline $\mathrm{S} 2 \mathrm{H} 2$ & 666 & 0.443 & 4.302 & -13.662 & 28.573 & S5H1 & 674 & 0.513 & 2.999 & -21.864 & 31.213 \\
\hline S2H3 & 670 & 0.367 & 4.954 & -61.636 & 33.393 & S5H2 & 674 & 0.189 & 3.170 & -24.919 & 14.480 \\
\hline S2H4 & 674 & 0.195 & 3.750 & -35.219 & 18.448 & S5H3 & 670 & -0.044 & 3.863 & -24.450 & 11.569 \\
\hline S2H5 & 674 & -0.380 & 3.762 & -33.878 & 13.736 & S5H4 & 631 & -0.065 & 5.319 & -26.118 & 18.950 \\
\hline S3H1 & 665 & 0.638 & 4.366 & -22.204 & 20.934 & S5H5 & 76 & -1.673 & 7.260 & -25.603 & 9.097 \\
\hline
\end{tabular}

Results of CAPM in panel A of Table 4 shows that for all 25 portfolios except $\mathrm{S}_{1} \mathrm{H}_{1}$ coefficients of common market risk factor $\left(R_{m}-R_{f}\right)$ are positive and significant at $1 \%$. At the same time, in 13 out of 25 cases the intercept is greater or less than zero. Moreover, in general the $\mathrm{R}^{2}$ value is quite low and the average $\mathrm{R}^{2}$ of the 25 portfolios is 0.27 . Thus, it can be inferred that single factor CAPM cannot adequately explain variation in portfolio returns. Results of FFM in panel B of the table shows that along with the common market risk factor both size and value factors are also significant. More specifically, the size factor in sixteen (including two negative values) cases is significant at $1 \%$ and in two cases it is significant at $10 \%$. Whereas, the value factor in nineteen (including five negative values) cases is significant at $1 \%$ and in one (five) cases it is significant at $5 \%$ (insignificant). The values of adjusted $\mathrm{R}^{2}$ in panel $A$ are smaller than values in panel $B$. The average $\mathrm{R}^{2}$ of the twenty portfolios is 0.39 and 0.27 for FFM and CAPM respectively. Similarly, in thirteen cases the intercept is greater or less than zero in both FFM and CAPM. Thus, it can be inferred that three factor FFM relative to single factor CAPM adequately explain variation in portfolio returns. However, the adjusted $\mathrm{R}^{2}$ values indicate that there are other relevant common factors involve in pricing stock in Pakistan.

If an asset pricing model is able to explain observed returns, the model's intercept should be equal to 
zero in the regression of portfolios' risk premium over risk-factors. Gibbons, Ross, and Shanken (GRS) (1989) have proposed a test to test the hypothesis of zero intercept. The GRS test reported in panel C of Table 4 shows that the average intercepts of FFM are lower, indicating that this model better explain risk and return relationship than CAPM. The Column headed F-test reveals that all intercepts are significantly different than zero in the case of CAPM but not so in case of FFM. Moreover, the adjusted $\mathrm{R}^{2}$ value for FFM is greater than that of CAPM (0.39 vs 0.27$)$.

Table 4: Time Series Regressions of 25 Portfolios - CAPM and Fama \& French Models

\begin{tabular}{|c|c|c|c|c|c|c|c|c|c|c|}
\hline \multicolumn{11}{|c|}{ Panel A - CAPM } \\
\hline Portfolios & S1H1 & S1H2 & S1H3 & S1H4 & S1H5 & S2H1 & S2H2 & S2H3 & S2H4 & S2H5 \\
\hline \multirow[t]{2}{*}{ Rm_Rf } & 0.191 & 0.395 *** & $0.475 * * *$ & $0.580 * * *$ & $0.675 * * *$ & $0.522 * * *$ & $0.306^{* * * *}$ & $0.519 * * *$ & $0.522 * * *$ & $0.530 * * *$ \\
\hline & $(1.305)$ & $(3.210)$ & $(5.447)$ & $(8.495)$ & $(9.910)$ & $(5.340)$ & $(5.755)$ & $(8.383)$ & $(12.266)$ & $(12.362)$ \\
\hline Constant & (1.078) & $(2.240)$ & $(1.151)$ & $(0.368)$ & $(-5.902)$ & $(3.305)$ & $(1.858)$ & $(1.358)$ & $(0.498)$ & $(-3.732)$ \\
\hline $\mathbf{R}^{2}$ & 0.003 & 0.017 & 0.047 & 0.105 & 0.137 & 0.048 & 0.051 & 0.102 & 0.195 & 0.198 \\
\hline Obs. & 576 & 603 & 606 & 619 & 622 & 573 & 614 & 618 & 622 & 622 \\
\hline Portfolios & S3H1 & S3H2 & S3H3 & S3H4 & S3H5 & S4H1 & S4H2 & S4H3 & S4H4 & S4H5 \\
\hline \multirow[t]{2}{*}{ Rm_Rf } & $0.472 * * *$ & $0.494^{* * *}$ & $0.568 * * *$ & $0.591 * * *$ & $0.822 * * *$ & $0.552 * * *$ & $0.651^{* * *}$ & $0.697 * * *$ & $0.694 * * *$ & $1.041 * * *$ \\
\hline & $(8.830)$ & (13.097) & $(17.435)$ & $(15.257)$ & $(15.315)$ & $(14.136)$ & $(21.251)$ & $(23.415)$ & $(18.541)$ & $(12.941)$ \\
\hline \multirow[t]{2}{*}{ Constant } & $0.517 * * *$ & $0.420 * * *$ & 0.022 & -0.204 & $-0.544 * * *$ & $0.569 * * *$ & 0.090 & -0.084 & -0.145 & $-0.788 * * *$ \\
\hline & $(3.094)$ & $(3.443)$ & $(0.207)$ & $(-1.629)$ & $(-3.137)$ & $(4.644)$ & $(0.912)$ & $(-0.878)$ & $(-1.200)$ & $(-3.027)$ \\
\hline $\mathbf{R}^{2}$ & 0.113 & 0.217 & 0.329 & 0.273 & 0.275 & 0.246 & 0.422 & 0.469 & 0.358 & 0.259 \\
\hline Obs. & 613 & 620 & 621 & 622 & 619 & 615 & 620 & 622 & 618 & 481 \\
\hline Portfolios & S5H1 & S5H2 & S5H3 & S5H4 & S5H5 & & & & & \\
\hline Rm_Rf & 0.744 *** & 0.820 *** & $0.956 * * *$ & $1.054 * * *$ & $1.354 * * *$ & & & & & \\
\hline \multirow[t]{2}{*}{ Constant } & $0.391 * * *$ & 0.040 & $-0.206^{* *}$ & -0.273 & $-2.223^{* *}$ & & & & & \\
\hline & $(5.123)$ & $(0.523)$ & $(-2.043)$ & $(-1.562)$ & $(-2.526)$ & & & & & \\
\hline $\mathbf{R}^{2}$ & 0.614 & 0.659 & 0.605 & 0.404 & 0.491 & & & & & \\
\hline Obs. & 622 & 622 & 618 & 580 & 480 & & & & & \\
\hline \multicolumn{11}{|c|}{ Panel B - Fama \& French Model } \\
\hline Portfolios & S1H1 & S1H2 & S1H3 & S1H4 & S1H5 & S2H1 & S2H2 & S2H3 & S2H4 & S2H5 \\
\hline \multirow[t]{2}{*}{ Rm-Rf } & $0.892 * * *$ & $0.658 * * *$ & $0.697 * * *$ & $0.698 * * *$ & $0.807 * * *$ & $0.791 * * *$ & $0.433 * * *$ & $0.621 * * *$ & $0.602 * * *$ & $0.589 * * *$ \\
\hline & $(6.294)$ & $(5.256)$ & $(8.340)$ & $(11.847)$ & $(20.859)$ & $(8.180)$ & $(7.745)$ & $(11.664)$ & $(15.498)$ & $(16.872)$ \\
\hline \multirow[t]{2}{*}{ SMB } & $2.437 * * *$ & $1.268 * * *$ & $1.365^{* * *}$ & $1.135 * * *$ & $1.484 * * *$ & $1.118 * * *$ & $0.461 * * *$ & $0.718 * * *$ & $0.685^{* * *}$ & $0.694 * * *$ \\
\hline & $(12.155)$ & $(7.113)$ & $(11.668)$ & $(13.757)$ & $(27.386)$ & $(8.394)$ & $(5.984)$ & (9.839) & (12.587) & $(14.181)$ \\
\hline \multirow[t]{2}{*}{ HML } & $-0.486 * * *$ & -0.059 & $0.602 * * *$ & $0.732 * * *$ & $1.064 * * *$ & $-0.299 * * *$ & -0.080 & $0.267 * * *$ & $0.460 * * *$ & $0.480 * * *$ \\
\hline & $(-3.069)$ & $(-0.425)$ & $(6.490)$ & $(11.214)$ & $(24.808)$ & $(-2.809)$ & $(-1.309)$ & $(4.536)$ & (10.687) & $(12.413)$ \\
\hline \multirow[t]{2}{*}{ Constant } & -0.430 & 0.654 & 0.777 *** & $0.786 * * *$ & $-0.255^{* *}$ & 0.469 & 0.157 & $0.536^{* * *} *$ & $0.483 * * *$ & -0.022 \\
\hline & $(-0.931)$ & (1.628) & $(2.877)$ & $(4.131)$ & $(-2.042)$ & $(1.542)$ & $(0.885)$ & $(3.200)$ & $(3.852)$ & $(-0.194)$ \\
\hline $\mathbf{R}^{2}$ & 0.221 & 0.094 & 0.261 & 0.402 & 0.729 & 0.163 & 0.107 & 0.252 & 0.437 & 0.493 \\
\hline Obs & 576 & 603 & 605 & 616 & 616 & 573 & 613 & 614 & 616 & 616 \\
\hline Rm-Rf & (9.719) & (14.058) & $(17.522)$ & (15.704) & (16.072) & $(13.786)$ & (19.653) & (20.884) & $(15.842)$ & $(11.322)$ \\
\hline \multirow[t]{2}{*}{ SMB } & $0.262 * * *$ & $0.203^{* * * *}$ & $0.216^{* * * *}$ & $0.363 * * *$ & $0.468 * * *$ & -0.050 & 0.007 & 0.010 & -0.066 & $0.182^{*}$ \\
\hline & (3.268) & $(3.587)$ & $(4.502)$ & $(6.797)$ & $(6.861)$ & $(-0.901)$ & $(0.159)$ & $(0.232)$ & $(-1.202)$ & (1.675) \\
\hline HML & $-0.141 * *$ & $-0.150 * * *$ & $0.101 * * *$ & $0.413 * * *$ & $0.761 * * *$ & $-0.139 * * *$ & -0.025 & $0.160 * * *$ & $0.297 * * *$ & $0.683 * * *$ \\
\hline & $(-2.271)$ & $(-3.352)$ & $(2.641)$ & $(9.780)$ & (14.103) & $(-3.102)$ & $(-0.684)$ & $(4.502)$ & $(6.851)$ & $(7.972)$ \\
\hline Constant & $0.330^{*}$ & $0.234 *$ & 0.119 & $0.217 *$ & $0.274 *$ & $0.456^{* * * *}$ & 0.058 & 0.097 & $0.210^{*}$ & -0.022 \\
\hline & (1.838) & (1.790) & (1.072) & (1.761) & $(1.741)$ & $(3.575)$ & $(0.536)$ & $(0.937)$ & (1.669) & $(-0.085)$ \\
\hline $\mathbf{R}^{2}$ & 0.136 & 0.246 & 0.363 & 0.405 & 0.480 & 0.271 & 0.422 & 0.485 & 0.404 & 0.348 \\
\hline Obs & 611 & 615 & 616 & 616 & 616 & 613 & 615 & 616 & 616 & 480 \\
\hline Portfolios & S5H1 & S5H2 & S5H3 & S5H4 & S5H5 & & & & & \\
\hline Rm-Rf & $0.764 * * *$ & $0.781 * * *$ & $0.910 * * *$ & $1.021 * * *$ & $1.253 * * *$ & & & & & \\
\hline & $(30.919)$ & $(30.886)$ & $(27.708)$ & (18.562) & (4.814) & & & & & \\
\hline SMB & $-0.061 *$ & $-0.165 * * *$ & -0.007 & 0.124 & -0.594 & & & & & \\
\hline & $(-1.751)$ & $(-4.644)$ & $(-0.143)$ & (1.598) & $(-1.528)$ & & & & & \\
\hline HML & $-0.202 * * *$ & -0.012 & $0.217 * * *$ & $0.342 * * *$ & 0.221 & & & & & \\
\hline & $(-7.384)$ & $(-0.434)$ & $(5.963)$ & $(5.588)$ & $(0.659)$ & & & & & \\
\hline Constant & $0.185^{* *}$ & 0.055 & 0.048 & 0.144 & $-2.106^{* *}$ & & & & & \\
\hline & $(2.318)$ & $(0.672)$ & $(0.451)$ & $(0.798)$ & $(-2.112)$ & & & & & \\
\hline $\mathbf{R}^{2}$ & 0.646 & 0.672 & 0.626 & 0.448 & 0.527 & & & & & \\
\hline Obs & 616 & 616 & 615 & 578 & 475 & & & & & \\
\hline & & & nel $C-M$ & n Absolut & Intercepts a & d Returns & ispersions & & & \\
\hline Models & GRS F & P-Value & GRS & Vald & P-Value & Mea & Absolute & pha & Avg. & dj R2 \\
\hline CAPM & 4.56 & 0.000 & & & 0.000 & & 0.010 & & & \\
\hline FEM & 1.41 & 0.113 & & & 0.000 & & 0.006 & & & 39 \\
\hline
\end{tabular}

\section{Conclusion}

In this study, we used weekly returns' data of up to 431 non-financial firms listed at the Karachi Stock 
Exchange over the period from January 1, 2006 to December 31, 2018 to investigate whether single factor (CAPM) or multi-factor model (Fama and French) can better capture variations in observed returns. For this purpose, we have used cross-sectional and time-series regressions to determine if these models could explain variation in excess portfolio returns. For choosing among the competing models, we use the GRS test. It is concluded that Fama \& MacBeth (1973) cross-sectional regression approach does not support the use of CAPM in Pakistan. In addition, results of the cross-sectional regression show that conditional relationship between beta and expected returns as proposed by Pettengill et al. (1995) offers limited applicability. However, time series-based asset pricing tests offer significant explanatory power, especially the Fama and French (1993) three factor model. Both the GRS-based test of regression intercepts and $\mathrm{R}^{2}$ indicate that Fama and French model better captures variations in observed stock returns than the CAPM. Future studies can consider more variables such as leverage, investment and, profitability factors to determine whether these factors can explain stock and portfolio returns. Moreover, in capital markets of developing or emerging economies the element of speculation is another aspect that the stakeholders (investors, analysts, researchers and others) might consider while determining risk and return relationship.

\section{References}

Banz, R. W. (1981). The relationship between return and market value of common stocks. Journal of financial economics, 9(1), 3-18.

Basu, S. (1977). Investment performance of common stocks in relation to their price-earnings ratios: A test of the efficient market hypothesis. The journal of Finance, 32(3), 663-682.

Black, F. (1972). Capital market equilibrium with restricted borrowing. The Journal of business, 45(3), 444-455.

Brennan, M. J. (1970). Taxes, market valuation and corporate financial policy. National tax journal, 23(4), 417-427.

Brockwell, P. J., \& Davis, R. A. (2016). Introduction to time series and forecasting. springer.

Chan, L. K., Hamao, Y., \& Lakonishok, J. (1991). Fundamentals and stock returns in Japan. The journal of finance, 46(5), 1739-1764.

Chen, N. F., Roll, R., \& Ross, S. A. (1986). Economic forces and the stock market. Journal of business, 383-403.

Chui, A. C., \& Wei, K. J. (1998). Book-to-market, firm size, and the turn-of-the-year effect: Evidence from Pacific-Basin emerging markets. Pacific-Basin finance journal, 6(3-4), 275-293.

Damodaran, A. (2016). Damodaran on valuation: security analysis for investment and corporate finance (Vol. 324). John Wiley \& Sons.

Fama, E. F., \& French, K. R. (1992). The cross-section of expected stock returns. the Journal of Finance, 47(2), 427-465.

Fama, E. F., \& French, K. R. (1993). Common risk factors in the returns on stocks and bonds. Journal of Financial Economics, 3-56.

Fama, E. F., \& MacBeth, J. D. (1973). Risk, return, and equilibrium: Empirical tests. Journal of political economy, 81(3), 607-636.

Fayyad, A., \& Daly, K. (2010). The volatility of market returns: a comparative study of emerging versus mature markets. International Journal of Business and Management, 5(7), 24.

Gibbons, M. R., Ross, S. A., \& Shanken, J. (1989). A test of the efficiency of a given portfolio. Econometrica: Journal of the Econometric Society, 1121-1152.

Haugen, R. A., \& Baker, N. L. (1991). The efficient market inefficiency of capitalization-weighted stock portfolios. The journal of portfolio management, 17(3), 35-40.

Hawawini, G. A., \& Michel, P. A. (1982). The pricing of risky assets on the Belgian stock market. Journal of Banking \& Finance, 6(2), 161-178.

Hawawini, G. A., Michel, P. A., \& Viallet, C. J. (1983). An assessment of the risk and return of French common stocks. Journal of Business Finance \& Accounting, 10(3), 333-350.

Hussain, F., \& Uppal, J. (1998). Distribution of stock returns in an emerging market: The Pakistani market. Pakistan Economic and Social Review, 36 (1), 47-72. 
Isakov, D. (1999). Is beta still alive? Conclusive evidence from the Swiss stock market. The European Journal of Finance, 5(3), 202-212.

Javid, A. Y. (2009). Test of higher moment capital asset pricing model in case of Pakistani equity market.

King, B. F. (1966). Market and industry factors in stock price behavior. the Journal of Business, 39(1), 139-190.

Lakonishok, J., \& Shapiro, A. C. (1986). Systematic risk, total risk and size as determinants of stock market returns. Journal of Banking \& Finance, 10(1), 115-132.

Lettau, M., \& Ludvigson, S. C. (2010). Measuring and modeling variation in the risk-return trade-off. In Handbook of financial econometrics: Tools and techniques (pp. 617-690). North-Holland.

Lintner, J. (1966). The Valuation of Risk Assets and Selection of Risky Investments in Stock Portfolio and Capital Budgets. Review of Economics and Statistics, 47(1), 13-47.

Litner, J. (1965). Security Prices, Risk and Max imal Gairs from Diversification. Journal of Finance, 587-615.

Maillard, S., Roncalli, T., \& Teïletche, J. (2010). The properties of equally weighted risk contribution portfolios. The Journal of Portfolio Management, 36(4), 60-70.

Markovitz, H. (1952). A property of Bessel functions and its application to the theory of two rheometers. Journal of Applied Physics, 23(10), 1070-1077.

Merton, R. C. (1973). Theory of rational option pricing. The Bell Journal of economics and management science, 141-183.

Mossin, J. (1966). Equilibrium in a capital asset market. Econometrica: Journal of the econometric society, 768-783.

Pettengill, G. N., Sundaram, S., \& Mathur, I. (1995). The conditional relation between beta and returns. Journal of Financial and quantitative Analysis, 101-116.

Reinganum, M. R. (1981). Misspecification of capital asset pricing: Empirical anomalies based on earnings' yields and market values. Journal of financial Economics, 9(1), 19-46.

Schwert, G. W. (1983). Size and stock returns, and other empirical regularities. Journal of financial Economics, 12(1), 3-12.

Sharpe, W. F. (1964). Capital asset prices: A theory of market equilibrium under conditions of risk. The journal of finance, 19(3), 425-442.

Sharpe, W. F. (1965). Risk-aversion in the stock market: Some empirical evidence. The Journal of Finance, 20(3), 416-422.

Shimko, D., \& Humphreys, B. (1998). End-User's Guide I Want to Be a Loan. RISK-LONDON-RISK MAGAZINE LIMITED-, 11, 95-96.

Solnik, B. H. (1974). An equilibrium model of the international capital market. Journal of economic theory, 8(4), 500-524.

Tang, G. Y., \& Shum, W. C. (2004). The risk-return relations in the Singapore stock market. PacificBasin Finance Journal, 12(2), 179-195.

Tinic, S. M., \& West, R. R. (1984). Risk and return: Janaury vs. the rest of the year. Journal of Financial Economics, 13(4), 561-574.

Tobin, J. (1958). Estimation of relationships for limited dependent variables. Econometrica: journal of the Econometric Society, 24-36.

Williams, J. T. (1977). Capital asset prices with heterogeneous beliefs. Journal of Financial Economics, 5(2), 219-239. 